\title{
KARAKTERISASI SIFAT KIMIA TEPUNG KACANG LAWA MERAH (Phaseolus vulgaris L.) DENGAN BEBERAPA PERLAKUAN PENDAHULUAN
}

\author{
Characterization of Chemical Properties of 'Lawa Merah' Bean (Phaseolus vulgaris L.) Flour with \\ Several Preliminary Treatments
}

Erynola Moniharapon, Sandra J. Nendissa, dan Dina Laiyan

Jurusan Teknologi Hasil Pertanian, Fakultas Pertanian, Universitas Pattimura, Ambon

Jl. Ir. M. Putuhena Kampus Poka Ambon 97233

\begin{abstract}
The objective of this study was to characterize the chemical properties of 'lawa merah' bean (Phaseolus vulgaris L.) with some pre-treatment. This study used a Complete Randomized Design with one factor which consisted of four treatment levels as follows: A0 (without pre-treatment), A1 (roasting for 20 minutes), A2 (boiling for 10 minutes) and A3 (roasting for 20 minutes and steaming for 30 minutes). The results showed that the best pre-treatment was A1 (roasting for 20 minutes), which produced 'lawa merah' bean flour with moisture content $7.81 \%$, ash content of $2.92 \%$, protein content of $26.75 \%$, fat content of $2.15 \%$, carbohydrate content of $5.92 \%$ and fiber content of $8.09 \%$.
\end{abstract}

Keywords: flour, red cross bean nut

\begin{abstract}
ABSTRAK
Tujuan penelitian ini yaitu untuk mengkarakterisasi sifat kimia tepung kacang lawa merah (Phaseolus vulgaris L.) dengan beberapa perlakuan pendahuluan. Pada penelitian ini menggunakan rancangan acak lengkap yang terdiri dari satu faktor dengan 4 taraf kombinasi perlakuan sebagai berikut A0 (Tanpa perlakuan), $A_{1}$ (sangrai 20 menit), $A_{2}$ (perebusan 10 menit) dan $A_{3}$ (pengukusan 30 menit). Hasil penelitian menunjukan perlakuan pendahuluan terbaik adalah perlakuan A1 (sangrai 20 menit) menghasilkan tepung kacang lawa merah dengan kadar air 7,81\%, kadar abu 2,92\%, kadar protein 26,75\%, kadar lemak 2,15\% dan kadar karbohidrat 59,2\% dan kadar serat 8,09\%
\end{abstract}

Kata kunci: kacang lawa merah, tepung

\section{PENDAHULUAN}

Kacang lawa merah (Phaseolus vulgaris L.) merupakan komoditas kacang-kacangan yang sangat dikenal masyarakat. Produksi kacang lawa merah di Indonesia tergolong cukup tinggi, yaitu mencapai 116,397-ton pada tahun 2010. Produksi kacang lawa merah di Maluku Tenggara Barat (MTB) mencapai 0,6 ton per hektar (BPS, 2012). Menghindari kehilangan hasil panen kacang lawa merah akibat kerusakan karena aktifitas mikroba yang dipicu oleh kadar air yang cukup tinggi maka perlu dilakukan penanganan pasca panen. Secara umum proses penanganan pasca panen masih terbatas dalam bentuk kacang kering.

Berdasarkan masalah penanganan pasca panen maka perlu dilakukan pengolahan lanjutan untuk mengolah kacang lawa merah menjadi tepung, dengan tujuan selain untuk memperpanjang umur simpan sehingga produk ini masih dapat dikonsumsi walaupun telah lewat musim. Teknologi penepungan merupakan salah satu proses alternatif produk setengah jadi yang dianjurkan karena lebih tahan lama disimpan, mudah dicampur dengan tepung lain, diperkaya zat gizi, dibentuk, dan lebih cepat dimasak sesuai tuntutan kehidupan moderen yang ingin serba praktis. Penelitian 
tentang tepung kacang lawa merah juga telah diaplikasikan secara luas, misalnya dalam pembuatan cookies (Ekawati, 1999) serta bahan pengikat dan pengisi pada sosis ikan lele.

Kabupaten MTB merupakan salah satu daerah penghasil kacang-kacangan yang didalamnya juga terdapat kacang lawa merah, khususnya di Desa Ritabel Kecamatan Tanimbar Utara sebagian besar petani membudidayakan dan memproduksi kacang lawa merah. Produksi kacang lawa merah untuk setiap petani cukup besar dan secara komersil nilai jual kacang lawa merah cukup besar yaitu berkisar antara Rp. 20.000-50.000 per kilogram berat kering, namun dalam pengolahan hanya masih sebatas kacang kering, kacang rebus, nasi kacang dan bubur kacang, dan selebihnya masyarakat setempat banyak menggunakan air rebusan kacang lawa merah sebagai obat penambah darah dan sebagai biasanya dianjurkan untuk diminum oleh ibu-ibu yang selesai bersalin untuk membersihkan dalam tubuh.

Melalui perkembangan teknologi pengolahan maka perlu dilakukannya diversifikasi produk. Salah satu bentuk produk olahan yang perlu dikembangan adalah pengolahan kacang lawa merah menjadi tepung. Produk tepung merupakan produk antara (setengah jadi), yang dapat dipakai untuk mengurangi penggunaan tepung terigu, karena dapat disubtitusikan dengan tepung terigu untuk mengolah berbagai jenis makanan seperti roti, cookies, mie, biskuit dan lain-lain. Kurangnya informasi yang memadai tentang pembuatan dan karakteristik tepung kacang lawa merah membuat aplikasi dalam pembuatan produk pangan belum teroptimalisasi secara luas. Kelemahan dari kacangkacangan adalah nilai gizi yang sebagian besar didominasi oleh asam fitat (Astawan, 2009) dan tingginya bau langu yang mengakibatkan produk akhir menjdi kurang diterima masyarakat.

Banyak hasil penelitian mengungkapkan bahwa kacang-kacangan selain sebagai sumber protein nabati, juga baik untuk karbohidrat, mineral, vitamin $\mathrm{B}$ dan mengandung karoten yang merupakan prekursor vitamin A. Kacang lawa merah seperti jenis kacang-kacangan lainnya, mengandung senyawa anti nutrisi yang menyebabkan pengurangan nialai gizi seperti asam fitat, oligosakarida, hemaglutinen / lektin dan anti tripsin (Pangastuti et al., 2013).

Berdasarkan latar belakang diatas maka perlu adanya suatu proses agar kacang lawa merah dapat bermanfaat bagi tubuh. Pengolahan kacangkacangan menjadi tepung diharapkan dapat mengurangi senyawa anti nutrisi. Berdasarkan hal tersebut maka penulis tertarik untuk melakukan penelitian tentang Karakterisasi Sifat Kimia Tepung Kacang Lawa Merah (Phaseolus vulgaris L.) Dengan Beberapa Perlakuan Pendahuluan.

\section{METODE PENELITIAN}

\section{Bahan}

Bahan yang digunakan adalah kacang lawa merah yang diperoleh dari Desa Ritabel, Kecamatan Tanimbar Utara, Kabupaten MTB.

\section{Pembuatan Tepung Kacang Lawa Merah}

Metode pembuatan tepung kacang lawa merah adalah sebagai berikut: $1 \mathrm{~kg}$ kacang lawa merah kering dicuci dengan air mengalir secara berulang-ulang sampai kotoran yang terapung di atas air tidak ada lagi. Selanjutnya kacang lawa merah yang telah bersih dilakukan perlakuan pendahuluan yaitu: $\mathrm{A}_{0}$ : tanpa perlakuan, $\mathrm{A}_{1}$ : sangrai 20 menit, $\mathrm{A}_{2}$ : perebusan 10 menit, $\mathrm{A}_{3}$ : pengukusan 30 menit, kemudian dihancurkan dengan diblender setelah itu dilakukan proses pengeringan, yang bertujuan untuk mengurangi kadar air tepung sampai kadar air maksimal 10\%. Kemudian di lakukan penepungan, setelah itu hasilnya disaring dengan menggunakan ayakan 80 mesh yang bertujuan untuk mendapatkan tepung kacang lawa merah.

\section{Pengamatan}

Pengamatan yang dilakukan yaitu analisis kimia meliputi kadar air, kadar abu, kadar protein, kadar lemak, kadar karbohidrat, dan kadar serat.

\section{Rancangan Percobaan dan Analisis Statistik}

Percobaan dilakukan dengan metode Rancangan Acak Lengkap (RAL) dengan empat taraf perlakuan dan tiga kali ulangan. Analisis keragaman digunakan untuk menganalisis data yang diperoleh dengan menggunakan software minitab 16. Jika terdapat beda nyata maka analisis dilanjutkan dengan uji BNJ pada taraf $0,05 \%$. 


\section{HASIL DAN PEMBAHASAN}

\section{Kadar Air}

Kadar air merupakan komponen penting dalam menentukan suatu produk pangan. Hasil analisis keragaman menunjukan bahwa perlakuan pendahuluan yang diberikan berpengaruh sangat nyata terhadap kadar air tepung kacang lawa merah yang diperoleh $(p<0,01)$. Hasil penelitian menunjukkan bahwa kadar air tertinggi diperoleh pada kombinasi perlakuan A2 (lama perebusan 10 menit) yaitu sebesar 10,01\% sedangkan kadar air terendah diperoleh pada kombinasi perlakuan A0 (tanpa perlakuan) sebesar 7,75\%.

Hasil uji BNJ menunjukan bahwa perlakuan A0 (tanpa perlakuan) yaitu sebesar $7,75 \%$ berbeda nyata dengan perlakuan A2 (perebusan 10 menit) $10,01 \%$ dan A3 (pengukusan 30 menit) yaitu sebesar $9,86 \%$, tetapi tidak berbeda nyata dengan perlakuan A1 (sangrai 20 menit) yaitu sebesar $7,81 \%$.

Perlakuan A0 (tanpa perlakuan) memiliki kadar air yang cukup rendah jika dibandingkan derngan kombinasi perlakuan pendahuluan untuk perlakuan A1, A2 dan A3. Hal ini disebabkan karena pada perlakuan A1 tidak dilakukan perendaman dan kombinasi perlakuan pendahuluan sehingga kadar air yang diperoleh sangat rendah. Pada perlakuan A1 (penyangraian) kadar air yang diperoleh sebesar 7,81\% sedikit terjadi peningkatan dari perlakuan A0 (tanpa perlakuan) sedangkan lebih rendah jika dibandingkan dengan perlakuan A2 (perebusan) dan A3 (pengukusan). Hal ini diduga perlakuan A1 (penyangraian) dapat menghilangkan sejumlah air dari kacang lawa merah karena terjadi penguapan air selama proses penyangraian sehingga kadar air yang dihasilkan lebih rendah.

Pada perlakuan A2 (perebusan) dan A3 (pengukusan) memiliki kadar air yang cukup tinggi, namun pada perlakuan A2 yaitu sebesar 10,01\% lebih tinggi jika dibandingkan dengan A3 yaitu sebesar $9,86 \%$. Tingginya kadar air pada perlakuan A2 disebabkan karena selama proses perebusan kacang lawa merah kontak langsung dengan air dan panas sehingga terjadi penyerapan air yang cukup besar karena kacang lawa merah semakin berpori sehingga kadar airnya lebih tinggi. Hal serupa juga terjadi pada perlakuan A3 (perebusan), namun pada perlakuan ini kacang lawa merah tidak langsung kontak dengan air tetapi dengan uap air yang menghantar panas sehingga permukaan kacang lawa merah juga semakin berpori dan dapat menyerap air yang diuapkan namun tidak sebanyak pada perlakuan A2 (perebusan) sehingga kadar air untuk pengukusan lebih rendah dari pada kadar air perebusan.

Proses pengeringan pada pembuatan tepung isolat protein kacang hijau bertujuan untuk menurunkan jumlah air yang dikandung oleh bahan. Kadar air merupakan salah satu parameter yang cukup penting pada produk tepung karena berkaitan dengan mutu. Semakin rendah kadar airnya, maka produk tepung tersebut semakin baik mutunya karena dapat memperkecil media untuk tumbuhnya mikroba yang dapat menurunkan mutu pada produk tepung. Kadar air tepung yang diperoleh berkisar antara $5,87 \%$ sampai $7,39 \%$. Kondisi ini sudah memenuhi syarat kadar air yang aman untuk tepung yaitu < $13 \%$ sehingga dapat mencegah pertumbuhan kapang (Simon, 2009).

Pengeringan juga dipengaruhi oleh keadaan kelembaban udara disekitarnya, Semakin kering udara maka makin cepat pula proses pengeringan yang terjadi. Udara kering dapat menyerap dan menampung uap air lebih banyak daripada udara lembab. Jika udara sekitar memiliki kelembaban yang tinggi uap air di atmosfer akan menjadi jenuh, sehingga udara sekitar tidak dapat lagi menangkap uap air yang dihasilkan dari proses pengeringan. Kadar air awal dalam bahan pangan ikut menentukan tingkat penerimaan konsumen, kesegaran dan daya tahan dari makanan tersebut, oleh karena itu penentuan kadar air perlu dilakukan untuk mengetahui kondisi suatu produk makanan (deMan, 1997).

Tabel 1. Karakteristik kimia tepung kacang lawa merah dengan beberapa perlakuan pendahuluan

\begin{tabular}{lcccccc}
\hline \multicolumn{1}{c}{ Perlakuan Pendahuluan } & $\begin{array}{c}\text { Kadar Air } \\
(\%)\end{array}$ & $\begin{array}{c}\text { Kadar Abu } \\
(\%)\end{array}$ & $\begin{array}{c}\text { Protein } \\
(\%)\end{array}$ & $\begin{array}{c}\text { Lemak } \\
(\%)\end{array}$ & $\begin{array}{c}\text { Karbohidrat } \\
(\%)\end{array}$ & $\begin{array}{c}\text { Serat } \\
(\%)\end{array}$ \\
\hline A0 : tanpa perlakuan & $7,75 \mathrm{a}$ & $3,76 \mathrm{a}$ & $24,92 \mathrm{a}$ & $2,04 \mathrm{ab}$ & $58,67 \mathrm{ab}$ & $7,4 \mathrm{c}$ \\
A1 : sangrai 20 menit & $7,81 \mathrm{~b}$ & $2,92 \mathrm{~b}$ & $26,1 \mathrm{a}$ & $2,1 \mathrm{a}$ & $59,2 \mathrm{a}$ & $8,09 \mathrm{~b}$ \\
A2 : perebusan 10 menit & $10,01 \mathrm{a}$ & $2,9 \mathrm{~b}$ & $25,17 \mathrm{a}$ & $1,94 \mathrm{~b}$ & $56,86 \mathrm{bc}$ & $8,38 \mathrm{ab}$ \\
A3 : Pengukusan 30 menit & $9,86 \mathrm{a}$ & $3,01 \mathrm{~b}$ & $25,05 \mathrm{a}$ & $1,94 \mathrm{~b}$ & $55,49 \mathrm{c}$ & $8,49 \mathrm{a}$ \\
\hline
\end{tabular}




\section{Kadar Abu}

Kadar abu merupakan sisa hasil pembakaran yang merupakan zat-zat organik berupa mineral yang dinyatakan dalam persen. Hasil penelitian menunjukan bahwa kadar abu yang diperoleh berkisar antara 2,9-3,76\%. Berdasarkan hasil analisis keragaman menunjukan bahwa perlakuan pendahuluan yang diberikan memberikan pengaruh sangat nyata terhadap kadar abu tepung kacang lawa merah yang diperoleh ( $\mathrm{p}<0,01)$. (Lampiran 1$)$. Rata-rata kadar abu tertinggi diperoleh perlakuan A0 (Tanpa Perlakuan) sebesar 3,76\% dan kadar abu terendah diperoleh pada perlakuan A2 (perendaman 24 jam dan perebusan 10 menit.

Hasil uji BNJ menunjukan bahwa perlakuan A0 (tanpa perlakuan) $3,76 \%$ berbeda nyata dengan perlakuan A1 (perendaman 24 jam dan sangrai 20 menit) $2,92 \%$, perlakuan A2 (perendaman 24 jam dan perebusan 10 menit) $2,9 \%$ dan perlakuan A3 (perendaman 24 jam dan pengukusan 30 menit) $3,01 \%$. Namun perlakuan A1 tidak berbeda nyata dengan perlakuan $\mathrm{A} 2$ dan $\mathrm{A} 3$.

Hasil penelitian yang ditunjukan pada Tabel 1 terlihat bahwa perlakuan A0 (tanpa perlakuan) memiliki kadar abu tertinggi yaitu sebesar 3,76\% dibandingkan dengan perlakuan A1, A2 dan A3. Hal ini disebabkan karena pada perlakukan A0 tidak dilakukan perendaman sedangkan pada perlakuan A1, A2 dan A3 dilakukan perendaman selama 24 jam yang mengakibatkan pelarut (air) mampu melarutkan mineral-mineral yang ada pada kacang lawa merah. Selain perendaman pada perlakuan A1, A2 dan A3 dilakukan pemanasan dengan metode yang berbeda yaitu penyangraian (A1), perebusan (A2) dan pengukusan (A3) yang diduga juga ikut berperan dalam penurunan kadar abu.

Sesuai dengan penelitian Mubarak (2005) pada kacang hijau, perendaman menunjukan tren penurunan kadar abu dari 3,76 menjadi 3,32 g/100 g. Adanya reduksi kadar abu selama perendaman dapat disebabkan karena larutnya molekul-molekul mineral kedalam media perendaman.

Hasil kadar abu terendah diperoleh perlakuan A2 (perebusan) dibandingkan dengan A1 (penyangraian) dan A3 (pengukusan), hal ini disebabkan karena pada proses perebusan dengan air, selain air mereduksi kadar abu pemberian panas akan mempercepat mineral-mineral larut dalam air sehingga kadar abu menjadi rendah. Hal ini sesuai dengan penelitian yang melaporkan bahwa penurunan kadar abu yang signifikan ini dapat terjadi karena larutnya mineral ke dalam media perendaman yang dipercepat dengan adanya pemanasan.

\section{Kadar Protein}

Protein merupakan zat yang penting bagi tubuh karena zat ini disamping berfungsi sebagai bahan bakar dalam tubuh juga berfungsi sebagai zat pembangun dan zat pengatur. Protein dapat digunakan sebagai bahan bakar apabila keperluan energi tubuh tidak dipenuhi oleh karbohidrat dan lemak (Winarno, 1993 dalam Suciati, 2012).

Perlakuan pendahuluan kacang lawa merah menghasilkan kadar protein sebesar 24,29-26,1\% . Hasil analisa keragaman menunjukan bahwa perlakuan pendahuluan yang diberikan tidak berpengaruh nyata terhadap kadar protein tepung kacang lawa merah.

Berdasarkan hasil penelitian yang ditunjukan pada Tabel 1 menunjukan bahwa kombinasi perlakuan pendahuluan terhadap kadar protein. Hasil penelitian menunjukan bahwa terjadi peningkatan kadar protein setelah diberi kombinasi perlakuan pendahuluan. Kadar protein tepung kacang lawa merah setelah diberi perlakuan pendahuluan lebih tinggi jika dibandingkan dengan tepung kacang lawa merah yang tidak diberi perlakuan pendahuluan.

Pada perlakuan A1 (penyangraian) terlihat bahwa kadar protein yang dihasilkan sangat tinggi yaitu sebesar $26 \%$ yang di ikuti oleh perlakuan A2 (perebusan) yaitu sebesar $25,17 \%$, perlakuan A3 (pengukusan) yaitu sebesar $25,05 \%$ dan kadar protein terendah diperoleh perlakuan A0 (tanpa perlakuan) yaitu sebesar $24,92 \%$.

Hasil penelitian menjelaskan bahwa A1 (penyangraian) mampu meningkatkan kadar protein cukup signifikan, namun pada kombinasi perlakuan pendahuluan A2 (perebusan) dan A3 (pengukusan) peningkatan tidak terlalu tinggi. Hasil tersebut serupa dengan penelitian Ertas (2011) yang menyebutkan bahwa perendaman dapat menurunkan kadar protein. Penelitian Pangastuti et al. (2012) Perlakuan pendahuluan berupa perebusan 90 menit diketahui lebih banyak menurunkan kandungan protein pada tepung kacang lawa merah baik dengan kulit maupun tanpa kulit.

\section{Kadar Lemak}

Lemak merupakan zat makanan yang penting untuk menjaga kesehatan tubuh manusia. Selain itu 
lemak juga merupakan sumber energi yang lebih efektif dibandingkan dengan karbohidrat dan protein. Satu gram minyak atau lemak dapat menghasilkan $9 \mathrm{kkal}$, sedangkan protein dan karbohidrat menghasilkan $4 \mathrm{kkal} / \mathrm{g}$ (Winarno, 1993).

Hasil analisa keragaman menunjukan bahwa perlakuan kombinasi pendahuluan berpengaruh nyata terhadap kadar lemak kacang lawa merah ( $\mathrm{p}<$ $0,05)$. Rata-rata kadar lemak tertinggi terdapat pada perlakuan A1 (perendaman 24 jam dan sangrai 20 menit) sebesar $2,1 \%$ yang berbeda nyata dengan perlakuan A2 (perendaman 24 jam dan perebusan 10 menit) sebesar $1,94 \%$ dan perlakuan A3 (perendaman 24 jam dan pengukusan 30 menit) sebesar $1,94 \%$, perlakuan A0 (tanpa perlakuan ) sebesar 2,04\%,.

Kadar lemak yang terlampau tinggi selain menjadi pertimbangan pada faktor gizi, juga dinilai kurang menguntungkan dalam proses penyimpanan tepung karena dapat menyebabkan ketengikan. Hasil penelitian menunjukan bahwa tanpa perlakuan (A0) menghasilkan kadar lemak sebesar 2,0\% dan terjadi peningkatan pada perlakuan A1 (penyangraian) sebesar $2,1 \%$ sedangkan terjadi penurunan perlakuan A2 (perebusan) dan A3 (pengukusan) yaitu sebesar $1,94 \%$. Penurunan kadar lemak diakibatkana adanya perendaman yang dapat mengaktifkan enzim, sehingga mampu mengubah lemak pada kacang lawa merah menjadi asam lemak bebas yang dapat larut dalam air yang dipercepat dengan proses pemanasan, sehingga terjadi penurunan kadar lemak. Hal ini sesuai dengan penelitian Pangastuti (2013) yang menyatakan bahwa mengaktifkan aktivitas enzim lipase yang dapat menghasilkan beberapa asam lemak bebas rantai pendek yang mudah larut ke dalam air pada media perendaman.

\section{Kadar Karbohidrat}

Karbohidrat mempunyai peranan penting dalam menentukan karakteristik bahan makanan, misalnya rasa, warna, tekstur, dan lain-lain (Winarno, 2002). Hasil analisis keragaman menunjukan bahwa perlakuan pendahuluan berpengaruh sangat nyata terhadap kadar karbohidrat $(\mathrm{p}<0,01)$. Rata-rata kadar karbohidrat tertinggi terdapat pada perlakuan A1 (perendaman 24 jam dan sangrai 20 menit) yaitu sebesar 59,2\% yang berbeda nyata dengan perlakuan A2 (perendaman 24 jam dan perebusan 10 menit) sebesar 56,86\% dan perlakuan A3 (perendaman 24 jam dan pengukusan 30 menit) sebesar 55,49\% tetapi tidak berbeda nyata dengan perlakuan A0 (tanpa perlakuan) sebesar 58,67\%.

Berdasarkan hasil penelitian yang ditunjukan pada Tabel 1 menunjukan bahwa kadar karbohidrat meningkat pada perlakuan A1 (penyangraian 20 menit) yaitu sebesar $59,2 \%$ dan terjadi penurunan yang cukup signifikan pada perlakuan A2 (perebusan 10 menit) yaitu sebesar $56,86 \%$, dan terus menurun sampai $55,49 \%$ pada perlakuan A3 (pengukusan 30 menit). Hal ini disebabkan karena pada proses perebusan dan pengukusan akan merusak mengendapkan dan menghilangkan kandungan karbohidrat dari kacang lawa merah karena terjadi permeabilitas dinding sel sehingga pati dapat mudah keluar dari dinding sel kacang lawa merah sehingga terjadi penurunan kadar karbohidrat.

\section{Kadar Serat Kasar}

Perlakuan konsentrasi menghasilkan kadar serat kasar kacang lawa merah sebesar 8,49-7,14\%. Hasil analisis keragaman menunjukan kombinasi perlakuan pendahuluan berpengaruh nyata terhadap kadar serat kasar $(p<0,05)$. Rata-rata kadar serat kasar tertinggi terdapat pada perlakuan A3 (pengukusan 30 menit) sebesar 8,49\% yang berbeda nyata dengan perlakuan A0 (tanpa perlakuan) sebesar 7,14\% dan perlakuan A1 (sangrai 20 menit) sebesar $8,09 \%$, tetapi tidak berbeda nyata dengan perlakuan A2 (perebusan 10 menit) sebesar 8,38\%.

Pada Tabel 1 terlihat bahwa dari setiap kombinasi perlakuan pendahuluan memberikan pengaruh yang berbeda terhadap kadar serat kasar dimana terjadi peningkatan kadar serat kasar. Peningkatan kadar serat kasar diakibatkan karena sebagian besar komponen-komponen gizi pada tepung lawa merah yang larut dalam media perendaman dan hanya menyisahkan serat kasar. pada Tabel 1, terlihat bahwa kadar serat kasar mulai terjadi peningkatan pada perlakuan A1 (sangrai 20 menit) akibat perendaman 24 jam terjadi kehilangan komponen gizi yang larut dalam air perendaman.

Peningkatan yang signifikan juga terjadi pada perlakuan A2 (perebusan 10 menit) dan A3 (pengukusan 30 menit) dimana pengurangan kandungan gizi terjadi lebih besar karena selain perendaman, perebusan dan pegukusan juga memiliki andil yang cukup besar untuk pengurangan kandungan gizi sehingga kadar serat kasar semakin tinggi, karena jika semua kandungan gizi hilang yang tersisah adalah serat kasar. 
Hal ini sesuai dengan penelitian Lintas dan Cappeloni (1988) dalam Muchtadi (2001), yang menyatakan bahwa kacang-kacangan rentan kehilangan komponen-komponen yang dapat larut seperti gula, protein larut, mineral, dan substansi pektat ke dalam air dan berakibat pada penurunan kadar bahan kering, sehingga akan meningkatkan kadar serat pangan.

\section{KESIMPULAN}

Perlakuan pendahuluan terbaik adalah perlakuan A1 (sangrai 20 menit) menghasilkan tepung kacang lawa merah dengan kadar air 7,81\%, kadar abu 2,92\%, kadar protein 26,75\%, kadar lemak $2,15 \%$ dan kadar karbohidrat $59,2 \%$ dan kadar serat $8,09 \%$. Kacang lawa merah berperan penting bagi tubuh selain itu umur simpan yang panjang (tahan lama) dibandingkan dengan kacang hijau, kacang kedelai dan kacang tanah.

\section{DAFTAR PUSTAKA}

Astawan, M. 2009. Sehat dengan Hidangan Kacang dan Biji-Bijian. Penebar Swadaya. Jakarta.

BPS. 2012. Dinas Tanaman Pangan Hortikultura dan Peternakan Kabupaten Maluku Tenggara Barat 2012. Badan Pusat Statistik-Maluku. Indonesia.

deMan, J.M. 1997. Kimia Makanan, Penerjemah: K. Padmawinata. ITB-Press, Bandung.

Ekawati, D. 1999. Pembuatan Cookies dari Tepung Kacang Merah (Phaseolus vulgaris L.) sebagai Makanan Pendamping ASI (MPASI). [Skripsi]. Jurusan Gizi Masyarakat dan Sumberdaya Keluarga, Fakultas Pertanian, Institut Pertanian Bogor. Bogor.

Ertas, N. 2011. The effects of aqueous processing on some physical and nutritional properties of common bean (Phaseolus vulgaris L.). International Journal of Health and Nutrition 2: 21-27.

Mubarak, A.E. 2005. Nutritional composition and nutritional factors of mung bean seeds (Phaseolus aureus) as affected by some home traditional processes. Food Chemistry 89: 489-495.

Muchtadi, D. 2001. Sayuran sebagai sumber serat pangan untuk mencegah timbulnya penyakit degeneratif. Jurnal Teknologi dan Industri Pangan 12 (1): 61-70.

Pangastuti, H.A., D.R. Affandi, dan D. Ishartani. 2013. Karakterisasi sifat fisik dan kimia tepung kacang merah (Phaeseolus vulgaris L.) dengan beberapa pelakuan pendahuluan. Teknosains Pangan 2 (1): 20-29.

Simon. 2009. Isolasi Protein dari Kecipir, Kacang Hijau, dan Kacang Tolo dengan Variasi $\mathrm{NaOH}$. [Skripsi]. Program Studi Teknologi Pangan. UNPAS Bandung.

Winarno, F.G. 1993. Pangan Gizi Teknologi dan Konsumen. Gramedia Pustaka Utama. Jakarta.

Winarno, F.G. 2002. Kimia Pangan dan Gizi. PT. Gramedia Pustaka Utama. Jakarta. 